\title{
Três poetas e uma cidade
}

\section{Fernando Fiúza Moreira}

Doutor em Literatura pela Université

Sthendhal Grenoble-3 (França) e Professor

Adjunto da Faculdade de Letras da

Universidade Federal de Alagoas.

Resumo: Aborda-se aqui as relaçōes entre a poesia lírica e o espaço da cidade. 0 corpus analisado é composto pelos poemas de Lêdo Ivo, Marcos de Farias Costa e Paulo Renault que têm Maceió como referente. O ponto de vista de cada eu lírico, ou locutor, é descrito, assim como os aspectos lexicais e de fatura poética. Ao fim, sāo repertoriadas algumas semelhanças e diferenças significativas entre as partes das obras em questāo.

Palavras-chave: poesia e espaço; poesia alagoana; Maceió; Lêdo Ivo; Marcos de Farias Costa; Paulo Renault
Résumé:On aborde ici les rapports entre la poésie lyrique et l'espace urbain. Le corpus analysé porte sur les poèmes de Lêdo Ivo, Marcos de Farias Costa e Paulo Renault, qui ont tous la ville de Maceió pour référent. Le point de vue de chaque moi lyrique, ou locuteur,décrit cette ville au moyen des aspects lexicaux de facture poétique. A la fin, on relève quelques ressemblances et quelques différences significatives entre les parties des oeuvres étudiées.
Mots-clés: : poésie et espace; poésie alagoana; Maceió; Lêdo Ivo; Marcos de Farias Costa; Paulo Renault 
. 
Se comparada a outras capitais nordestinas como Recife, Salvador ou São Luís do Maranhão, Maceió é uma cidade nova, não completou ainda duzentos anos - seu status de capital de Alagoas é de 1839. E por ser nova capital de uma pequena província suscitou poucos poemas e menos ainda foi usada como cenário na prosa de ficção. Mesmo assim, quando se pesquisa o assunto, sem o intuito exaustivo de historiador, mas tão-somente de crítico, encontram-se poemas, partes de livro e até livro cujo tema principal é esta cidade.

Atento à questão proposta por este número temático - a cidade - e ao espaço dado a cada ensaio, este artigo limitar-se-á a três poetas do século XX - Lêdo Ivo, Marcos de Farias Costa e Paulo Renault - que aqui nasceram, foram criados e tomaram Maceió como tema em determinados trechos de suas trajetórias literárias. A escotha desses três nomes para analisar a relação entre lírica e cidade é, de certa forma, arbitrária - como de resto todo trabalho acadêmico na área de Humanas, em que a subjetividade do pesquisador é filtrada pela objetividade "científica". No caso, os critérios de escolha foram: terem os poetas obras publicadas (portanto, inéditos não foram pesquisados) em livros (também não pesquisamos revistas, jornais, panfletos, etc.) disponíveis ainda no mercado (não se recorreu a bibliotecas). Não foram levados em conta poetas que escreveram ocasionalmente sobre Maceió, como é o caso de João Cabral de Melo Neto, Jorge Cooper e Sidney Wanderley, por exemplo, nem se incluíram letras de canções sobre esta cidade (que há em número abundante), quando não pela polêmica que cerca o assunto, o que desviaria sobremaneira o curso dos argumentos.

Estudar as relações da cidade com o texto literário é estudar o espaço, e o estudo do espaço sofreu certo boicote das críticas estruturalista e semiótica que suspenderam o referente, concentrando seu poder de fogo nas relações entre significante e significado. A título de exemplo, basta ler a seguinte sentença de Umberto Eco: "[...] extirpar a idéia daninha de Bedeutung ${ }^{\prime}$ de toda investigação semiótica, como resíduo que impede a com-
'A Bedeutung é o objeto a que o signo faz referência. (Cf. ECO, 2001, p. 12) 
preensão da natureza cultural dos processos de significação." (2001, p. 12) Mas passada a época do "terror", o referente, ou "realema", para usar um sinônimo de cunho estruturalista, retomou seus direitos. Segundo Bertrand Westphal (2004, p.33-34)

[...] il va de soi que tout texte qui reproduit un espace humain, et qui donc transpose un pan du réel, se positionne à l'égard de ce même référent. Cela est vrai depuis le tout début, âge de l'encorevide odysséen ou argonautique, et aujourd'hui encore, peut-être plus que jamais, à l'époque du trop-plein postmoderne.

Westphal utilisa um argumento incontestável: "[...] si Stendhal mentionne Nancy, c'est qu'il songe à Nancy. A moins que Stendhal eût été schizophrène. [...] Si Nancy n'avait pas été Nancy, il aurait suffi de modifier son nom pour élider toute connexion avec un référent obvie." (ibidem, loc. cit.). A cidade de Nancy seria então um "designador rígido" (ibidem, p.38). No entanto, para este crítico, "tout espace représenté l'est partiellement et partialement - , car il est focalisé en fonction du point de vue limité d'un observateur subjectif' (ibidem, p. 39).

O conceito de unidade de lugar não se encontra nem em Aristóteles, nem em Horácio - foi derivado, pelos retóricos do Renascimento, do conceito de unidade de ação - (cf. DUBOST, 2004, p.20) e só ganhará status categórico nos estudos literários quando Lessing, em seu Laooconte (1766), dividir as artes entre aquelas que acontecem no tempo (literatura, música, dança) e aquelas que acontecem no espaço (arquitetura, pintura, escultura.) (CAZANAVE, 2002, p.192), o que é coerente com os princípios que regerão o Romantismo - naquele momento sendo gestado - posto que o espaço histórico aí ganha uma importância que não havia no cânone clássico, em que o espaço era convencional e idealizado. O século XIX vai acentuar mais ainda as relações entre texto e espaço, sobretudo na voga realista-naturalista, onde se encontra a preocupação tanto com a descrição detalhada e "fiel", quanto a de situar a narrativa em lugares 
verificáveis (cf., por exemplo, a geografia carioca na obra de Machado de Assis).

Mas se estudar "espaço", "lugar", "referente" ou "realema" em prosa de ficção pode causar ainda certo malestar conceitual aos herdeiros semiconscientes do estruturalismo e da semiótica, problematizar a relação de espaço com a lírica, onde o referente é rarefeito, torna-se árduo. Mas para certos críticos, como Bernadette Hidalgo Bachs, é um motivo de ânimo. É o que ela faz em seu ensaio "La spatialité de l'entre-deux dans les trois premiers recueils de Pedro Salinas" (2004). Para esta crítica, a importância do espaço no texto literário dá-se pelos "índices paratextuais", pelas "notificações localizantes", pela "focalização descritiva" e pela "escolha do léxico" (p. 303-304). E serão esses instrumentos conceituais que nos guiarão na análise de alguns poemas.

Mas antes será preciso uma abordagem, ainda que breve, sobre a relação tema-forma da cidade na lírica moderna. Na poesia ocidental, a cidade só se tornará tema e ao mesmo tempo influenciará a forma a partir do romantismo - e pelo lado negativo. Até então, a temática clássica desdenhara a cidade em detrimento do campo idealizado, do céu e do inferno. É preciso esperar por um Wordsworth (cf. HYDE, 1999, p. 276), por um Shelley, descrevendo Londres como um inferno (cf. BENJAMIN, 1994 , p. 55-56), ou pelo Nerval (2005) em "Le peuple" (p. 64), "Notre Dame de Paris" (p. 86) e "Le coucher du soleil" (p. 91). Mas tais poetas tratam a cidade residualmente em suas obras. Será Baudelaire o responsável pela entronização da cidade na poesia, embora paradoxalmente não descreva nem a população nem a cidade em sua obra (BENJAMIN, 1994, p.116).

Segundo Macolm Bradbury (1999, p.76), "Sempre existiu uma íntima ligação entre a literatura e as cidades. Aí se encontram as instituiçōes literárias básicas: editoras, patronos, bibliotecas, museus, livrarias, teatros, revistas." Ou seja, a ligação seria do ponto de vista institucional. No entanto, para este autor, 
Por muito tempo, os escritores e intelectuais abominaram a cidade: o sonho de escapar a seus vícios, sua imediaticidade, seu espraiamento, sua velocidade, seu próprio modelo de homem, tem sido a base de uma profunda dissidência cultural, visivel naquela moda literária mais constante, a pastoral, que pode ser uma crítica à cidade ou uma pura e simples superação dela. [...] Mas, apesar disso, os escritores e intelectuais iam constantemente às cidades, em alguma busca essencial em termos de arte, experiência pessoal, história moderna, ou uma realização mais plena de seus dotes artísticos. O poder de atração e repulsão da cidade tem fornecido temas e posturas que atravessam profundamente a literatura, na qual a cidade aparece mais como metáfora do que como lugar físico. (p. 77)

Com a crescente urbanização e a venda da força de trabalho por parte do escritor, no lugar do mecenato estatal e/ ou aristocrático, o olhar sobre a cidade, o corpo a corpo com ela, o deixar-se influenciar por suas formas, a reconfiguração da dominância dos sentidos - "a predominância da atividade visual sobre a auditiva" (BENJAMIN, 1994, p.35-36) - foram inevitáveis, mesmo a contragosto. E como escrever contra é um ato por excelência moderno, escrever contra a cidade virou moeda corrente: "[...] a cidade é intrinsecamente não-poética [...]; e, no entanto, a cidade é intrinsecamente o material mais poético dentre todos. Depende de como se a olhe." (HYDE, 1999, p.276).

Foi preciso Baudelaire, com sua repulsa ao natural - basta ver, pelo viés do deslizamento metonímico, seu elogio à maquiagem (cf.1976, p.715) -, dar o selo de legitimidade aos temas e formas urbanos. Para Benjamin, "a rejeição ao 'natural', deve-se tratar antes de tudo em conexão com a cidade grande como tema do poeta." (1994, p. 155) E, quanto à forma (dos poemas de As Flores do Mal), "Sua versificação é comparável à planta de uma grande cidade, na qual alguém pode movimentar-se despercebido, encoberto por quarteirões de casas, portais, cocheiras e pátios. Nessa planta indicam-se às palavras 
seu lugar exato [...]." (1994, p. 95). Mas se em Baudelaire a presença da forma da cidade é ainda pelo viés da planta cartográfica com sua ordem geométrica, no modernismo será a cidade real que entrará em cena. Segundo Bradbury (op.cit., p. 78-79):

O caos cultural alimentado pela cidade populosa em crescimento constante, Torre de Babel contingente e poliglota, é reproduzido como análogo ao caos, contingência e pluralidade nos textos literários modernos, no desenho e na forma da pintura modernista. [...]. A escrita modernista mostra uma grande tendência a encerrar a experiência dentro da cidade e a adotar o poema ou o romance urbano como uma de suas formas principais.

Quase todos os textos que tratam da relação da literatura com a cidade tomam como referência as cidades grandes dos países do primeiro mundo. Como então aplicar tais conceitos ao estudo da relação das obras de três poetas com uma cidade pequena de um país periférico? Tais instrumentos conceituais terão validade? Como ponto de partida para a reflexão, sim. Cabe ao crítico, no entanto, adaptar tais conceitos para o uso nos trópicos.

\section{Lêdo Ivo - a cidade lembrada}

Maceió aparece desde o primeiro livro de Lêdo Ivo (1924), As Imaginações (1940-1943) (Poesias completas, p.45-54)2, pelo viés metonímico. Já no poema de abertura, "Esmeralda" (p. 47), encontram-se duas palavras ("farol" e "mar") recorrentes em toda sua obra - tanto em prosa quanto em verso - mas, sobretudo, na parte que tem sua cidade natal como realema. $O$ quinto poema desta primeira recolha leva como título "Praia do Sobral" (situada no litoral sul de Maceió):
${ }^{2}$ As citações dos poemas de Lêdo Ivo, utilizadas neste artigo, foram retiradas da edição da Topbooks, de 2004, intitulada Poesia completa, de agora em diante $\mathrm{PC}$.

$[\ldots]$

Praia debruçada sobre seu corpo,

o amor era a gratidão marítima

e as ondas obedeciam ao fremir de suas coxas. 
Doralice era a utilidade que sob o sol ou sob a lua me afastava do céu.

Era o crepúsculo invasor de alguma manhã

Sonhos caminhando, tardes náufragas, noites grandes,

Doralice era como a lagoa da terra em que nasci: me perturbava e me acendia.

Era a areia quente

onde o sol de minha infância se nutria.

A noite vinha do sexo de Doralice

para o litoral que era

como um colchão onde se amava.

Depois Doralice vomitou a infância

e eu fiquei, menino, na praia sonhando (p. 50-51)

Nessas três últimas estrofes do poema (num total de cinco) já se encontram presentes quatro das linhas mestras de toda sua poética: 1) o mar (e todo um léxico derivado) em "Praia debruçada sobre seu corpo / o amor era a gratidão marítima" e ainda nos sintagmas "tardes náufragas" e "areia quente", além da retomada do campo semântico marinho no símile que se encontra nos três primeiros versos da última estrofe: " $A$ noite vinha do sexo de Doralice / para o litoral que era/ como o colchão onde se amava."; 2) o sonho, no início da quarta estrofe: "Sonhos caminhando", além do campo semântico do onírico em "A noite vinha do sexo de Doralice" e do fecho do poema: "é eu fiquei menino, na praia, sonhando "; 3) o sexo, que perpassa todo o poema. Sua alta voltagem erótica inscreve-se desde o primeiro verso ("Esperava que ela afastasse de mim os seios puros") ao começo da última estrofe; 4) e, por fim, a memória, evidente desde o tempo (o passado) escolhido para os verbos empregados (na sua grande maioria no pretérito imperfeito do indicativo, só o dístico final vem no perfeito) até versos claramente memorialísticos, como "Doralice era como a lagoa da terra em que nasci, onde o sol da minha infância se nutria" e, o último, "e eu fiquei, menino, na praia sonhando".

Em "A infância redimida" (p. 199-200), de Cântico 
(1947-1949) ( $P C$, p. 189- 256), Maceió está sob o epíteto de "minha cidade". O poema trata da descoberta da poesia e da conseqüente alegria, inoculado de reflexão metapoética: "Tenho um ritmo longo demais para louvar-te, Poesia./ Maior, porém, era a beira da praia de minha cidade/Onde, menino, inventei navios antes de tê-los visto". O fecho é uma constatação da precedência das palavras com relação às coisas: "Não és senão um sonho de infância, um mar visto em palavras."

A segunda parte de Linguagem (1950-1951) (PC, p. 257$334)$ intitula-se "A terra natal" e seus 20 poemas são permeados pela presença física de Maceió. "Soneto da Ponta da Terra" (p. 294) traz no título um bairro praiano da cidade e a marca da memória que caracterizará os "poemas maceioenses" de Lêdo Ivo. Os dois últimos versos de "Barra do rio" (p. 301) sustentam a nota memorialística enxertada do campo lexical atrelado à cidade: "Dos mangues e das locas de goiamuns, vem a sombra/ de minha infância dormindo na podre corografia." Esta parte do livro encerra-se com "Ponta Verde" (p. 305), outro bairro praiano, que à época do livro era um vasto coqueiral, cujo único traço humano era uma capela (já demolida), e hoje é um dos bairros habitado pela elite alagoana. Aqui, mais uma vez a memória: "Palma de sal e seiva, minha infância/ te viu, coqueiro, sombra simulada." E assim se finda: "Parti-me deste sol, vim desta sombra,/ e a vida bebe os ares, como as palmas."

Nos livros seguintes, Maceió e seus bairros não serão títulos nem temas de poemas, mesmo que o campo semântiCo a ela ligado apareça em Magias (1955-1960) (PC, p. 381-418), em poemas como "Iara" (p. 406) e "Lacraia" (p. 414). Mas a cidade emergirá com toda força, sobretudo na primeira parte - "Lugar de nascimento" -, em Finisterra (1965-1972) ( $P C$, p.523-588), que é, como constata Ivan Junqueira, “ $[\ldots]$ o livro que marca o regresso definitivo do autor às suas origens e, talvez, o mais comovido que nos deixou até agora. E esse retorno ao paraíso perdido da infância estará presente, em maior ou menor grau, em todas as coletâneas poéticas que ainda iria publicar." (PC, p. 36).

"Lugar de nascimento" contém 28 poemas, mas nem 
todos trazem Maceió como referente - em 7 poemas, o realema constitui-se de outros municípios alagoanos. Os outros poemas podem ser divididos entre aqueles que trazem, desde o título, a cidade de Maceió inscrita metonimicamente, como, por exemplo, em nomes de bairro ("Jaraguá" e "Pajuçara"), de construções ("Homenagem a um semáforo" e "Os anjos da igreja do Rosário") ou, simplesmente, aquele intitulado "Planta de Maceió"; e ainda aqueles em que, pela escolha do léxico, a cidade se faz presente de maneira implícita.

Desde o poema de abertura, "Minha terra" (p. 527) - espécie de mapa lexical, semântico e imagístico desta parte do livro -, torna-se claro a abordagem memorialística. A quarta estrofe - o poema contém vinte e três, cada uma formando uma unidade semântica independente e todas compostas de três versos polimétricos - contém o tempo do verbo que marca a memória: "Entre casas de maribondos/ e caranguejeiras imóveis / a tarcle me iluminava." A estrofe seguinte recorre igualmente ao mesmo tempo verbal:" Eu soletrava a ferrugem/ de navios sem nome que a lama/ das lagoas mastigava. 'Uma pequena mostra aqui recolhida traz o campo lexical recorrente nesta fase da obra do poeta, e não só da obra em verso, mas em sua prosa de ficção (Cf. Ninho de Cobras, por exemplo): "caranguejeiras", "ferrugem", "navios sem nome”, "lama”, "lagoas". Mas, retomando as marcas textuais da memória, ainda neste poema vejam-se as estrofes 14 e 15, com a anáfora a não deixar dúvidas: "Foi na infância que aprendi a ver-te,/ ó sol que me ilumina. E um arco-íris/ abriu-se entre as arraias no céu pálido. / Foi na infância que aprendi amar-te,/ fêmea, que meu espanto confundia/ com as caranguejeiras." Do ponto de vista geográfico, espacial, Maceió só se insinua nas estrofe 18, 19, 20 e 21 pela via de notificações localizantes:

De cima das dunas eu via o mundo:

escória azul ao longe,

mar curvo de navios.

Como o universo era belíssimo!

A nuvem que roçava os trapiches 
fulgia no celeiro das águas.

No fim dos trilhos da Great Western

entre balduínas sedentas

e dormentes cravados na água

o branco farol de minha terra

clareava jaqueiras acocoradas

sempre grávidas como lavadeiras. (grifos meus)

O poema encerra-se com uma constatação que serve de comentário à poética do autor: a fértil promiscuidade entre o onírico e a matéria: "Sempre juntei no mesmo prato/ as espinhas dos meus peixes/ e o sobejo dos meus sonhos."

A nota memorialística continua soando em "Quando os navios apodrecem" (p.533) - poema que contém desde o título uma das fixações temáticas do poeta a partir desta fase: a decomposição das coisas. Interessante contrastar duas visões diametralmente opostas a respeito do papel do mar em dois poetas amigos e da mesma geração: em Lêdo Ivo, o mar é um agente de putrefação, enquanto em João Cabral, o mar é um agente sanativo3. "Naquela manhã de domingo/ Vi os navios do Império bebidos pelas águas quase negras/ e lancei um grito que assustou meu pai". Nesses três versos, temos a marca da memória e a presença alusiva da lagoa que cerca uma parte da cidade de Maceió conotada "pelas águas quase negras." Este poema ainda possui um diálogo intertextual com a Odisséia, especificamente com o episódio das sereias: "Porque lembrara: do tombadilho de um daqueles navios/ que cruzaram as ilhas douradas do dia, eu vira/ as sereias cantando na praia."

O poema seguinte, "Os morcegos" (p. 533), também não traz, como o anterior, nenhuma notificação localizante precisa de Maceió, mas através do léxico sabese que o espaço que sedia o poema é esta cidade: "alfândega", "a casa de nosso pai," "luz do farol". A memória aqui é explicitada no verso que abre a segunda estrofe: $A$ casa de nosso pai era cheia de morcegos. Na última estrofe, a casa paterna é retomada: "Ao morrer, nosso pai deixou (a mim e a meus oito irmãos) / a sua casa onde à noite chovia 
pelas telhas quebradas."

"Homenagem a um semáforo" (p. 534), breve poema de apenas três longos versos, também não traz um nome próprio que esteja ligado diretamente a Maceió: é pelo léxico e pelos objetos que a cidade se faz presente: "Aquele semáforo junto ao mar, na minha infância. / Sempre amei as coisas que indicam ou significam algo/ - tudo o que, em silêncio, é linguagem. É notável aqui a reflexão ao mesmo tempo analógica e metapoética: o eu lírico compara a poesia ao semáforo: ambos em silêncio são linguagem - o semáforo, por ser apenas luz, a poesia, por, modernamente, ter-se calado, virado antes coisa de ver do que de ouvir.

No poema em prosa "O cata-vento" (p. 534), todos os verbos vêm no passado e quase todos no imperfeito do indicativo, marca evidente da memória que perdura - além do aposto que inicia o segundo e último parágrafo - "Menino, eu caminhava [...]". Maceió aqui é apresentada tanto pelo epíteto "minha cidade natal", quanto pela geografia que lhe é característica: "entre a duna e o mar". O poema seguinte, "O guarda-livros" (p. 535), traz a marca biográfica e confessional, pois o pai do poeta é nomeado no verso "ó velho Floriano Ivo". Aqui, eu lírico e eu empírico se fundem - a leitura de Confissöes do poeta (2004) confirma a fusão.

"Cama e mesa" (p. 537) traz, no primeiro verso, um local de Maceió que não mais existe (o banheiro de cego): "No Banheiro do Cego / amamos sobre tábuas duras". Em seguida, temos uma palavra trazendo a cor local em toda sua cintilância popular: "peniqueira" em: "Ó sol de querosene / nos peitos molengos / de uma peniqueira. A ressaltar, ainda, o sintagma "peitos molengos", típico do baixo calão maceioense, como também, mais adiante, "lengalenga" e "desengonçados”. A memória também aqui é explicitada nos versos seguintes: "Que sabão lavará / a minha infância suja / que nessa comilança / já hoje se lambuza?"

"Jaraguá" (p. 539) traz Maceió desde o título, pois este é o bairro onde se encontra o porto que, por sua vez, deu origem à cidade. Ainda nesta calha da origem, só que agora verbal, no terceiro verso encontra-se "maçaiós", de 
onde deriva o nome da cidade e que o Aurélio (1986, p.1058) define como "lagoeiro, no litoral, formado pelas águas do mar nas grandes marés, e também pelas águas da chuva”. A terceira e última estrofe do poema é exemplar quando não por concentrar as linhas mestras da poesia desta primeira parte ("Lugar de nascimento") de Finisterra:

$[\ldots]$

Só quem nasceu junto às vagas, entre barricas, [balanças e espinhas de carapeba, conhecerá, raiada a aurora, esse dia carcomido pelo sal quando nos balcões dos armazéns de secos e molhados os gatos estremecem pressentindo trombas-d’água [e naufrágios e as varandas dos velhos sobrados são esculturas do tédio. Ainda agora sob minha cama dormem caranguejos. [E no meu sono de estiva os navios se espalham sobre as ondas oxidadas [como uma ninhada de ratos.

Aqui pode-se observar todo um léxico atado ao porto e ao mar, o agente corrosivo que é este último, assim como a permanência da infância na idade adulta: "Ainda agora sob minha cama dormem caranguejos". A cidade se torna presente através da memória e do sonho, que, para um poeta da linhagem de Lêdo Ivo, são tão ou mais palpáveis do que a realidade. O porto de Jaraguá, embora não nomeado, será invocado através do campo semântico em "Nascimento do dia" (p. 541). Mas aqui os verbos no pretérito perfeito do indicativo circunscrevem a lembrança, não há uma ponte com o presente, como no caso de "Jaraguá".

Em "Planta de Maceió” (p. 546), o poeta tomará a cidade como um corpo, e um corpo presente, vivo. A notar, antes de tudo, a ambigüidade do título, pois "planta" aqui pode ser lida à primeira vista como plano cartográfico, mas, depois da leitura do poema, também na sua primeira acepção: a de vegetal, de que tem raízes, de que vinga em determinado torrão. Os verbos estão majoritariamente no presente e o poeta se posiciona, situa-se, toma o partido inevitável de onde nasceu, mesmo que a determinação de tal lugar caiba ao destino e não à vontade do indivíduo. Neste poema, desde o 
início, a memória cede espaço ao presente:

O vento do mar rói as casas e os homens.

Do nascimento à morte, os que moram aqui andam sempre cobertos por leve mortalha de mormaço e salsugem. [...].

Aqueles que não partiram, como partiu o poeta, são vítimas dos "dentes do mar" e de "um sol de areia". O locutor se posiciona claramente no espaço: "Foi aqui que nasci, onde a luz do farol / cega a noite dos homens e desbota as corujas". A putrefação causada pelo clima quente e úmido e pela proximidade do mar é mais uma vez posta em cena: "A ventania lambe as dragas podres,/ entra pelas persianas das casas sufocadas/ e escalavra as dunas mortuárias/ onde os beiços dos mortos bebem o mar". O olhar severo e antitético sobre a paixão dos homens que aí habitam vem em seguida: 'Mesmo os que se amam nesta terra de ódios/ são sempre separados pela brisa/ que semeia a insônia nas lacraias/ e adultera a fretagem dos navios. O local de nascimento é reiterado nos cinco versos finais: "Este é o meu lugar, entranhado em meu sangue/ como a lama no fundo da noite lacustre./ E por mais que me afaste, estarei sempre aqui/ e serei este vento e a luz do farol,/ e minha morte vive na cioba encurralada". A salientar, ainda, as operações metafóricas: nos dois primeiros versos pelo uso do "como" (o símile), e no quarto verso pelo emprego do verbo "ser" (a metáfora em si). No terceiro verso ("por mais que me afaste, estarei sempre aqui") e no verso final ( $\mathrm{e}$ minha morte vive [...]"), encontra-se o oxímoro. Em todos estes três tropos observa-se a fusão do eu enunciacior com o espaço enunciado.

O poeta ainda terá Maceió, nesta primeira parte de Finisterra, como espaço em dois poemas: "Os anjos da igreja do Rosário" (p. 548) e "Pajuçara” (p. 549), em que a notificação localizante vem no título. No primeiro, os anjos (pelo viés estético) e Deus (pelo viés moral) são vistos de maneira depreciativa e uma dúvida acicata o leitor: a culpa é do escultor dos anjos que os fez feios? De um 
tosco artesão da província? Ou será o olhar ateu do poeta que os deforma? No segundo poema, uma tensão emana dos quatro dísticos entre a concretude do localizável Pajuçara, bairro e praia da cidade - e o enigma de corte oracular, e nada de estável se consegue - "Pajuçara" seria então um nome de navio? A ambigüidade, uma das marcas da função poética, segundo Jakobson, rege de maneira ostensiva todos os poemas sobre Maceió que se encontram em Finisterra e esta am(fi)bigüidade é explicitada num terceto do poema de abertura ("Minha terra"): "Vindo das ilhas inacabadas/ nunca aprendi a separar/ o que é da terra e o que é da água."

Maceió reaparecerá como referente em Mar Oceano (1983-1987) (PC, p. 743- 790), desde a primeira frase do segundo poema, "A morte de Elpenor" (p. 743): "Os bordéis de Maceió iluminam a minha adolescência”. Aqui são postos em cena, como já o tinham sido em alguns poemas de Finisterra, a memória, o mar, o clima mormacento, o bairro de Jaraguá, as prostitutas e a Odisséia de Homero (não mais as sereias, mas o palácio de Circe). "Ponta da Terra" (p. 766), bairro de Maceió, é o título de um haicai heterodoxo (com apenas 11 sílabas poéticas, quando o canônico traz 17): "O mar crepita/ pepita azul/ entre pedras". A remarcar a aliteração em / $\mathrm{p} /$, bilabial sonora que mimetiza a pancada do mar na pedra. "O nome dos navios" (p. 777) é outro poema (em prosa) de fundo memorialístico e alusivo à cidade natal, mesmo que não haja nome próprio que o atrele diretamente a ela, mas em que os acidentes geográficos são suficientes para tanto:

Domingo à tarde, ele nos levava para o passeio interminável, conduzindo-nos, através de ruas monótonas, até o começo da praia.

Víamos as dunas. Elas caminhavam junto ao Mar Oceano como uma branca romaria de mulheres. Depois contemplávamos os navios. Nas proas negras havia sempre um nome que a distância dissolvia. $[\ldots]$

Em Curral de Peixe (1991-1995) (PC, p. 867-943), 
antepenúltima recolha do poeta, Maceió volta como espaço de maneira bem mais saliente do que em Mar Oceano e desde o primeiro verso do primeiro poema, "As ferragens" (p. 873):

Em Maceió, nas lojas de ferragens, a noite chega ainda com o sol claro nas ruas ardentes. Mais uma vez o silêncio virá incomodar os alagoanos. O escorpião reclamará refúgio no mundo desolado. E o amor se abrirá como se abrem as conchas nos terraços do mar, entre sargaços. Nas prateleiras, os utensílios estremecem quando as portas se cerram com estridor. Chaves-de-fenda, porcas, parafusos, o que fecha e o que abre se reúnem como uma promessa de constelação. E só então é noite nas ruas de Maceió.

Se aqui a cidade é vista pelo prisma a princípio mercantil, o léxico recorrente, de quando se trata dos "poemas maceioenses", se faz notar: "escorpião", "conchas", "terraços do mar", "sargaços". Note-se ainda que não há um cunho de memória no poema, os verbos estão no presente e no futuro, ao contrário de "O Peixe" (p. 887), onde os verbos encontram-se no passado, desde o primeiro terceto: "O peixe estava fora d'água./ Era um peixe vivo/ na praia da Pajuçara". "Hospital do câncer (Maceió)" (p. 888) não traz, além do nome da cidade entre parênteses no título, nada que se refira espacial ou especificamente a Maceió - é de supor que a idéia do poema tenha vindo neste local ou que ali morreu uma pessoa querida, pois qualquer cidade cairia justo entre os dois parênteses, afinal o tema do poema é universal: o câncer, aqui tratado por "caranguejo" - teria sido então tal palavra, pertencente ao campo semântico de Maceió, pois prato aí apreciado, a responsável pelo nome da cidade no título? "Anoitecer em Maceió” (p. 889) é juncado do léxico característico dos poemas sobre a cidade natal do poeta: "semáforo", "mar", "naufrágio", "navios", como o são "Porto de Jaraguá" (p. 889) e "Promotório" (p. 890). No último verso deste, observa-se 
mais uma vez a declaração de pertencimento do eu lírico à cidade: "longe de vós serei um exilado". O pai voltará em "Reaparição do meu pai" (p. 894), obviamente todo em clave onírico-memorialística (um sonho transcrito) e onde mais uma vez a cidade se anuncia: "Meu pai ia e vinha no centro de Maceió". Este poema, assim como "As ferragens", difere, sob o ângulo do espaço invocado, dos outros, majoritariamente atrelados ao mar, pois é o centro da cidade, o que lhe há de mais urbano, que emerge dos versos: "De vez em quando meu pai parava num lugar:/ $\mathrm{Na}$ junta comercial, numa loja de ferragens, à porta de uma sapataria./ Com seu olhar de míope contemplava o rosto de Carole Lombardi no cartaz do cinema Floriano./ Entrava no bar Colombo para mijar.[...]". "Perto de Maceió" (p. 914) é um soneto em que a atmosfera onírica se anuncia desde o primeiro decassílabo: "Como um farol aceso em pleno dia" - aqui também todo léxico recorrente estará presente, sobretudo o de campo semântico marinho. "Trapiche da barra" (p. 921), outro soneto em decassílabos e outro bairro a intitular um poema, traz também o mar como irradiador lexical para tratar, em tom camoniano, do tempo que passa: "Tudo é vário e inconstante e tudo muda/ como a vaga infiltrada nos mourões/ [...]". "Ponta Verde" (p. 924), outro bairro e outro soneto (agora em hexassílabos), é construído sobre antíteses, do começo ("A minha noite é dia") ao fim ("Livre e cativo. Toda/ liberdade é cárcere”.), e traz no terceiro verso do segundo quarteto o sintagma, no plural, que dá título ao livro: "currais de peixe", construção que marca a paisagem litorânea de Maceió com grande impacto interrogativo: até o mar aqui é privado, até o peixe tem dono?

"O Barulho do mar" (p. 953), que se encontra em O rumor da noite (1996-2000) (PC, pp. 945 a 1020), a cidade aparece já no primeiro verso: "Na tarde de domingo, volto ao cemitério velho de Maceió/ onde os meus mortos jamais terminam de morrer/ [...]". E mais adiante: "Digo aos meus mortos: Levantai-vos, voltai a este dia inacabado/ que precisa de vós, de vossa tosse persistente e de vossos gestos enfadados/ e de vossos passos nas ruas tortas de Maceió. Retornai aos sonhos insípidos/ e às janelas aber- 
tas.sobre o mormaço./ [...]". Aqui o eu lírico volta à cidade natal não só para rever seus mortos, mas, com a força do verbo, tentar ressuscitá-los. Mas é apenas um lapso de grandeza, pois logo em seguida conforma-se e consola-se com o mundo mineral e marinho: [...]/ o silêncio dos mortos me diz que eles não voltarão./ Não adianta chamálos. No lugar em que estão, não há retorno./ Apenas nomes em lápides. Apenas nomes. E o barulho do mar".

Plenilúnio (2001-2004) (PC, p. 1021-1064), último livro do poeta, traz "O mormaço" (p. 1033), onde não se encontra nenhum nome próprio ligado a Maceió, mas, pelo léxico e pela geografia, deduz-se facilmente que o espaço invocado no poema, dividido em tercetos, é a cidade natal: "mormaço", "sargaço", "dunas", "mar", "destroços dos navios", "açúcares", "trapiche”, etc., além das seguintes estrofes não deixarem dúvida: (7) "Não posso perder minha pátria/ de vento e areia./ Minha pátria de caranguejos."; (8) "Aqui é meu reino./ Apenas o vento do mar/ no abraço seminal"; e (11) "Nada me dispersa./ Como o fogo e a água/ sou o meu lugar de nascimento". Em "Minha Pátria" (p. 1027) o intertexto (negativo) com Fernando Pessoa ("Minha pátria é a língua portuguesa") serve para reiterar o pertencimento à cidade e a tudo que a caracteriza. O poema sintetiza léxico e imagens utilizados pelo poeta desde seu primeiro livro toda vez que escolhe Maceió como espaço: Minha pátria não é a língua portuguesa./ Nenhuma língua é a pátria./ Minha pátria é a terra mole e peganhenta onde nasci/ e o vento que sopra em Maceió". O poema encerra-se reiterando a negação (pátria não é a língua), numa atitude típica dos românticos, para quem a palavra estava aquém das emoções e das coisas: Nenhuma língua enganosa é a pátria./ Ela serve apenas para que eu celebre a minha grande e pobre pátria miúda,/ minha pátria disentérica e desdentada, sem gramática e sem dicionário,/ minha pátria sem língua e sem palavras".

Lêdo Ivo é um poeta caudaloso, pletórico, escreveu em todos os gêneros, escreveu em prosa e em verso, e em toda sua obra o espaço físico é privilegiado - é um poeta para quem "a geografia existe", como dizia de si Théophile 
Gautier. São incontáveis os nomes de lugares em sua obra. Seu escopo geográfico vai da rua ao continente. Escreveu sobre muitas cidades, tanto de seu estado e do seu país, quanto de outros países. O papel de outras cidades (Rio de Janeiro, Paris, Roma, por exemplo) presentes em seus poemas poderia também ser estudado. Os poemas aqui catalogados e resumidamente analisados são aqueles em que Maceió se faz presente não só de maneira explícita, através de nome da cidade ou nomes próprios a ela pertencentes, mas da geografia e do léxico característicos. É a cidade portuária tropical, entreposto marítimo que muitas vezes parece sacada de uma página de Joseph Conrad, uma cidade rudimentar, cujos sinais de urbanidade quase que se limitam aos armazéns de secos e molhados e às lojas de ferragens, cidade quente, úmida, mormacenta, infestada de animais peçonhentos (lacraias, cobras, morcegos, lesmas, formigas) e de que os homens querem evadir-se pelo mar oceano, o caminho que lhes resta a bordo dos navios sem nome, mas ainda assim fincada tão fundo na alma do poeta, que a ela sempre volta, seja em sonho, seja em corpo, nem que seja para constatar que seus mortos jamais ressuscitarão. A Maceió invocada por Lêdo Ivo fisicamente não existe mais - se é que um dia existiu - , mudou vertiginosamente como a Paris de Baudelaire: "Le vieux Paris n'est plus (la forme d'une ville/ Change plus vite, hélas! que le coeur d'um mortel) (1975, p. 85)".

\section{Marcos de Farias Costa - a cidade insultada}

Em comparação a Lêdo Ivo, Marcos de Farias Costa (1951) é um poeta magro, econômico, no que diz respeito ao número de livros de poemas publicados, e, dentro destes livros, os poemas que têm Maceió como espaço invocado. Em sua primeira recolha, $O$ amador de sonhos (1970-1981), nada há em que se possa localizar a cidade como referente. Tem-se que aguardar a segunda, Ócios do oficio (1984), para ver a cidade emergir, mesmo assim pelo viés metonímico, ou seja, por um elemento estreitamente a ela ligado, o mar, em "Thalassa! Thalassa" (p. 15). Mas 
"Cemitério Novo" (p. 39) não deixa dúvida sobre a presença de Maceió, posto que traz como título uma instituição da cidade e um bairro, desde o primeiro verso do primeiro dístico: "Cemitério do Trapiche/ Vivo, largo, ao ar livre". No terceiro dístico, outro bairro é convocado: "Cemitério translúcido que se avista/ desde o Farol a se perder de vista". Deve-se salientar dois aspectos deste poema que caracterizam a visão do autor sobre a cidade - e que se prolongarão nos poemas seguintes: 1) a cidade entra em cena na obra através do espaço reservado aos mortos, numa postura desencantada, sombria, que será uma das dominantes de sua poética; 2) a cidade aqui presente não é mais invocada pela natureza que a cerca ou permeia, mas pelo que há de construído, de humana intervenção (ainda que a natureza surja em outros poemas). Os dois últimos dísticos são exemplares desses dois aspectos: Necrópole no centro da cidade:/ Circunferência que está em toda parte.// Hotel final de mil inquilinos/ Quietos: sejam homens ou meninos". Palavras como "necrópole", "hotel", "inquilinos" e o sintagma "centro da cidade" em localização sintática estratégica traduz a visão da cidade já bastante urbana, onde o papel da natureza é mitigado.

Será na recolha seguinte, $A$ quadratura do círculo (1991), que Maceió ganhará importância na obra de Marcos de Farias Costa, a ponto da segunda das três partes em que o livro é dividido se intitular "Maceiomaquia". A posposição ao nome da cidade do elemento de composição "maquia" (do grego -makhía: combate, batalha, luta, disputa) é sintomático do postura do eu lírico perante a cidade. Dos 22 poemas que compõem esta parte do livro, nem todos trazem indicações espaciais, deduzindo-se daí um alto grau de subjetividade na seleção das peças, em que o "geocrítico" se move em campo minado. Um exemplo é o primeiro poema, "Com uma garrafa na cabeça" (p. 43), em que a presença da cidade só pode ser inferida de forma negativa, ou seja, pela evasão para outras paragens, no caso, Bizâncio, onde o locutor se refugia para ficar Tonge dos grupos, das viragos/ que me gelaram a vida. [...]". O poema seguinte, "Sob o 
vulcão" (p. 44), homônimo do romance de Macolm Lowry (uma das fixações literárias do poeta), insiste na mesma tecla do anterior: o álcool como agente de fuga do lugar hostil: "Bebo bebo sem controle/ Até que a alma se evole".

Em "Maceiomaquia" (p. 45), terceiro poema, homônimo desta parte do livro, Alagoas se confunde com Maceió, ou melhor, Alagoas é Maceió: 'Sou tão possessivamente alagoano/ que descuido ser cidadão do mundo". Nestes dois primeiros versos vê-se a declaração de pertencimento incondicional a um espaço. O poema é uma fusão de solilóquio de cunho existencialista ("Que é ser alagoano? Ontoalagoas/ ou mapa comiserado de tristeza?") e diálogo do locutor com uma suposta ouvinte: "Que é Alagoas? Alegria e angústia?/ Diga-me, ó flor humana, que significa um homem/ dito amante de seu chão, enamorado de medo?/ [...] Se não entendes esta ternura, fim de conversa: não/ colherás o diafragma da paixão. Serás mais uma tonta/ traumatizada pela província". A cidade é nomeada uma única vez: "Maceió se debate em mim como bandeira/ lambida pelo vento, tatalando no espaço, / feito fumaça em boca de moça que devaneia o amado". Através do símile a cidade se faz bandeira e fumaça, ambos comparantes artificiais. Poema construído sobre contradições e dualidades dissonantes (típicas da poesia moderna), sobre a luta (-maquia) entre as partes, seus dois últimos versos negam a afirmação dos dois primeiros: "Sou alagoano, pela metade, que o resto é saudade/ que eu sonhei, saudade que eu saudei".

"James Joyce" (p. 49) começa com um símile que serve ao mesmo tempo de intertextualidade e declaração de pertencimento à cidade natal: "James Joyce carrega Dublin/ como eu carrego Maceió em mim”. O verbo "carregar" denota peso, fardo inevitável. O dístico seguinte, em operação metonímica, desloca o foco do autor comparante para a obra, por um viés de significativa ambigüidade em que "Ulysses" remete, ao mesmo tempo, ao romance de Joyce e ao episódio da epopéia homérica: "Aqui todos os açúcares e areias/ Untam Ulysses: episódios das Sereias!", em que "açúcares e arei- 
as" substituem a cera da cena hipotextual. A cidade é nomeada no penúltimo dístico, sempre na clave comparativa (e, no caso, paronomástica e neologística, mimetizando dois procedimentos tipicamente joycianos): "Dublar Dublin? Trilagoas, Entimemática,/ Maceió, Ítaca, Bares. Nausicaa”.

A cidade aparece mais uma vez em título em "Com Maceió na cabeça” (p. 56) e é a primeira palavra do poema, composto de seis quartetos heterométricos e brancos. A dualidade dissonante aqui está a postos para abordar os dois planos geográficos da cidade (a restinga e o platô): "Maceió. Melancólico tabuleiro. / Brutal geografia marítima - / Verdes cabelos dos mapas/ Onde os becos cantam à bala". Esse tom, ao mesmo tempo sombrio e irado, pontua o que se segue, até o fim: "Nomes dos bairros d'água: Bebedouro, Poço, Vergel, Pontal,/ Subúrbios operários que praguejam/ Contra a peste das residências ricas". Todo o poema também recorre à presença marcante da água, que a cidade traz desde o nome: "Mares horizontes", "[...] Cilada/ Abrupta do porto, das enchentes; / Águas lúcidas em sol e lua." e "sarjeta crônica".

"Delirium in Maceió" (p. 58) lança mão mais uma vez da tecla etílica (o álcool como único passaporte que permite a evasão do ingrato burgo natal) e encerra como começa, empregando um neologismo: "uisqueci-me/ De ti: Sfumato vi-me/ sem elixir". "Mãeceió” (p. 59), outro neologismo, dá título ao último poema de "Maceiomaquia" que traz a cidade como tema. Aqui o intertexto (e interbiografia) dá-se com, além de Joyce, Kafka, que fornece o primeiro verso: “Uma mãezinha com garras!'/ Assim definiu Franz Kafka/ a sua cidade de Praha”. O paralelo entre as cidades vem no terceto seguinte: "Maceió é a mãe possessa/ que torce o pescoço do cisne,/ se suas asas nascem avessas". O terceiro terceto reúne as três cidades (mães ingratas): "Maceió. Praga. Dublin./ Três territórios terríveis,/ tristes terrores insulares". A cidade ainda é insultada, como aquela "De leite azedo no peito,/ com gosto de cianureto." e "pesadelo universal".

A comédia de Eros - poemas galantes (1997) que, 
como indica o título, é um livro organizado em torno de um tema (o sexo), traz dois poemas onde a cidade aparece como referente. O primeiro é "Maceió na cama" (p.43), que, como os poemas anteriores, oscila entre a melancolia e insulto: Maceió em mim começa,/ onde me finda a alegria". A cidade transfigura-se em fêmea humana a partir dos dois últimos versos da segunda quadra: "levo Maceió para cama, / copulo num meretrício". A antropomorfização da cidade continua na terceira quadra: "Maceió sonha de dia,/ com dia que não virá". Na quinta, a metáfora a transporta para clima antípoda: "Maceió, última Thule,/ Islândia de Jaraguá". Ao final, o tom insultuoso é trocado por um fatalismo conformado: Maceió é minha sina,/ minha tortura bendita./ Maceió, fêmea bonita,/ incestuosa menina".

"Jaraguá" (p. 49) é o segundo poema, neste despudorado porno-livro, em que a cidade se apresenta, mas não é nomeada, e sim seu bairro-ventre, não como porto, mas tão-somente como zona meretrícia. Aqui um outro escritor é convocado para a intertextualidade: Rimbaud, na segunda das cinco quadras: "Juventude perdida,/ toda sem firmeza,/ por delicadeza/ eu perdi a vida”. Mais uma vez, a dualidade irresoluta ponteia o texto, vide os dois últimos versos: "gorda cornitude/ magra Margarida".

Seu último livro de poemas, Doce estilo novo (2000), é formado por uma antologia dos livros anteriores e mais uma parte, a última, de inéditos, "Poemas profanos". É aí que o poeta abordará Maceió, em dois poemas: "Soneto em Jatiúca" (p. 134) e "Limando o Lima" (p. 139). O primeiro é composto por versos de busca do amor, cujo cenário é a praia que se encontra no título e nos dois tercetos: "nesta praia selvagem onde me deito/ e rolo em suas areias infinitas, até perder o senso, a voz, a cuca.// No delito de amar, armo o meu leito,/ e toco em tuas curvas tão bonitas,/ entre as águas azuis da Jatiúca". A praia é o lugar que acende a fantasia da posse ilícita, posto que mesmo "selvagem", já é urbana, é bairro populoso. O poema alude a um hábito afetivo arraigado: o namoro nas piscinas naturais formadas por arrecifes na maré baixa. No segundo poema, "Limando o Lima", a cidade 
aparece na primeira estrofe antes como o espaço que abriga a vida literária de Alagoas: "Em Maceió, a poesia/ prima pelo bordão:/ o vate Jorge de Lima/, acendeu seu lampião". Todo o texto é uma série de fragmentárias questões sobre o estilo e a importância de Jorge de Lima. É interessante notar que, na quinta quadra, Jorge de Lima é chamado de "O poeta de União" (União dos Palmares, sua cidade natal), como para marcar o pertencimento do poeta criticado à outra cidade que não Maceió.

Os "poemas maceioenses" de Marcos de Farias Costa apresentam algumas características que lhe traçam um perfil bastante singular. A primeira é a presença da literatura, ou seja, da intertextualidade e/ou interbiografia com outras obras e escritores. $O$ poeta se posiciona diante de sua cidade assim como outros autores se posicionam perante as suas. A segunda é a presença do álcool (como possibilidade de fuga da cidade) e do sexo, ambos temas recorrentes em toda sua obra. A terceira é uma postura entre melancólica e insultuosa com respeito a Maceió, advinda, por sua vez, do parti pris do boêmio, o verdadeiro adversário moral do burguês. Este poeta, ao contrário de Lêdo Ivo, que partiu aos 19 anos de Maceió (e para onde só retorna em visitas esporádicas), jamais morou em outra cidade (é de linhagem machadiana), portanto não tem o filtro da distância que doure a víbora, que retenha as mágoas - e é no palco do poema que os exacerbados e contraditórios sentimentos para com a cidade entram em jogo: "maceiomaquia".

\section{Paulo Renault - a cidade declamada}

Está-se aqui diante de um caso particular: primeiro porque o mais novo dos três poetas estudados, no entanto já falecido (1958-2003); segundo porque teve apenas dois livros publicados, mesmo assim, sendo um póstumo; terceiro porque este último livro tem como título Maceió Cidade Aberta (2004), formado por 25 poemas que trazem a cidade como eixo central. A Maceió 
que lhe serve de realema é distinta daquela de Lêdo Ivo e da de Marcos de Farias Costa: nem é uma cidade recriada pela memória, como a do primeiro, nem de rarefeito referente e insultada, como a do segundo, mas uma cidade com os traços da atual e que aponta para um futuro apocalíptico em poemas polvilhados de lugares reais, de nomes próprios, e tratada com desencantada ternura. É também o menos "literário" dos três, tanto pela intertextualidade mitigada, quanto pelas fortes marcas de oralidade em todo o livro.

O poema de abertura, "Vou embora para Nova York" (p.4), traz, desde o título, o desejo, por parte do locutor, de evasão ("Pretendo viajar o mundo inteiro") do burgo periférico, perdido às margens do Atlântico Sul: "Talvez, nesses lugares encontre/ Alguma coisa nova,/ Menos desprezível que a rua do Comércio, ou o Bar do Chopp, ou a praça dos Martírios". Será em Nova York, centro do mundo, que o eu lírico comprará alma nova, pois que vendeu a velha ao diabo no primeiro verso. $\mathrm{O}$ tom do poema é entre irônico e divertido, quando não pelas palavras de baixo calão. "Escuta a cidade" (p.10) pressupõe uma interlocutora dormindo:

Acorda, amor!

E sinta a praia pajuçarense,

Onde os homens passam às cinco,

Os executivos de luxo andam sempre apressados, De bermuda, camisa de meia e tênis branco E só cumprimentam a si próprios E imaginam que estão se preparando para revolucionar.

Nesta última estrofe, o locutor observa a cidade com seus hábitos atuais (o cooper no calçadão da praia, o ensimesmamento e a pressa urbana) e emprega o verbo "revolucionar" como intransitivo, quando manda a norma ser transitivo direto, o que instala no leitor a seguinte dúvida: o que pensa revolucionar um executivo, se as revoluções não lhe são normalmente atribuídas? Se a paisagem burguesa e turística da orla é vista pelas lentes da ironia, a do centro proletarizado 
da cidade, povoada pelo lúpen, representado, em "Tratadores da classe operária" (p, 62) pela prostituta, merece o olhar e o ouvido terno do poeta: "Chore sentada na quina da calçada do edifício Breda/ E demore as suas lágrimas/ Até enchurrar a praça do Montepio". A pobreza do centro e cercanias ainda contrasta com a beleza praiana em "A ilha do rato" (p.65), "O shopping das favelas, / O boulevard dos miseráveis, / O bazar dos infortunados", onde o locutor passante se depara com "Valetas podres, pássaros presos e sagüis,/ Pedaços de rádios, bicicletas e fogões,/ Cuscuz e carne ensebada". Mas a ternura pela cidade já desponta em a "Prisão das ruas" (p. 12), quarto poema do livro: "Quem colocaria Maceió nos braços para dizer que a ama?/ O Jaraguá inóspito, o Bebedouro ignoto/ E o centro da cidade exíguo. / Como afagar uma cidade desamorada, inculta, terna e carente?". E a ternura ainda nos primeiros versos de "Cidade Aberta" (p. 84), penúltimo poema: "A cidade estava mergulhada no pó e estilhaçada./ A cidade coube em minhas mãos,/ Tomei-a e soprei-a, tirei a fuligem que a cobria,/ Depois, juntei os pedaços e emendei-a".

A cidade será deslocada no tempo ( Como a que quis sempre antiga,/ Ou igual a do futuro") e antropormifizada ("[...] os teus seios enormes/ E as tuas pernas a passarem sobre mim") em "Cidade encantada" (p. 16) e "Cidade aberta" (p. 84): "A quero como amante, como cúmplice,/ Companheira de viagem/ A quero, insurrecta". Em "Ruas" (p. 22), encontra-se a fusão do real com o imaginado literário numa passagem anafórica: "Rua das Quixabas,/ Rua estreita do Rosário,/ A rua de Bandeira,/ A rua dos Anjos,/ A rua de Drummond,/ A rua de Pessoa.../ ... A Quintino Bocaiúva,/ ... a Firmino Vasconcelos". O poema, desde o início, é feito nesta clave em que flutuam, amalgamados, desejo e realidade: "Ruas amarelas, aproveitei seus encantos/ Para desejar outras ruas/ Que não fossem aquelas/ Que sujaram meu coração/ Nessas tardes em que chove".

Um tema marcante (e premonitório) deste livro 
é a morte - tanto a morte da cidade (e do que lhe é contíguo), quanto a do locutor. Em "Memória dos manguezais" (p. 26), a morte é uma possibilidade de fuga: "Vou morrer!/ $\mathrm{Na}$ cidade encantada, / $\mathrm{Na}$ hora e no dia que me der vontade/ De deixar a praia da Pajuçara,/ A Lagoa do Norte,/ Os ouriços da Jatiúca". Em um poema que trata o tempo a contra-pêlo, pois começa com a morte e termina com a infância, é dado o local de nascimento do eu empírico: "Desde o dia em que nasci na bomba da Marieta", e logo em seguida do eu lírico: "Depois, na guilhotina dos manibus,/ Às margens do canal da Levada,/ Onde os muçuns, os caboges, as galinhas d'água,/ Os socós, as capivaras, os goiamuns, / Ucas, jararacas e corais anoitece$\mathrm{ram} / \mathrm{E}$ de manhã foram direto para o céu/ O céu das palavras". Diante da destruição do meio-ambiente, só os nomes dos bichos restarão. Até o locutor está morto: "E hoje não direi que estou vivo/ E afirmo que estou morto,/ Falecido pelos cantos, sussurros e imagens verdes, Sons e assovios". No poema seguinte, "Espelhos da cidade" (p. 30), Maceió encontra-se destruída, mas busca refazer-se: "E alheia a tudo/ Que lhe impuseram ser sagrado,/ E tenta sacrificadamente juntar aquilo, / O qual não perderam tempo/ Em apagar-lhe da memória,/ Tudo aquilo que lhe era mais caro". A cidade, como um arqueólogo, ou um pobre paciente, procura coisas ("becos", "esquinas", "bares", "livros raros", "quadros de artistas", "fotografias", "mapas") "Que a lembrem quando era jovem e bela". Olhando-se no espelho, ela percebe "[...] que algo de sórdido lhe aconteceu." Mulher, a cidade entrega-se ao locutor:

Descubro que a alma da cidade também é minha,

Também me pertence

E que suas lágrimas

Encharcarão de novo o alagadiço,

Limparão o riacho Maceió

E derramar-se-ão no mar da praia da avenida,

Da Pajuçara, da mãe do norte,

Expulsando de lá os augúrios

Que despassarinizaram, desarborizaram,

Desvitalizaram os leitos sagrados das águas

Que brotavam de seu coração. 
Este final insere o poema na casa da utopia, caracterizada sintaticamente pelos verbos no futuro: as lágrimas da cidade, aquática desde nome, serão capazes de refazê-la após ter se tornado "devassa, injusta e fria."

Mas se as lágrimas foram capazes de reerguer a cidade destruída, o mesmo não ocorrerá em "Se vocês pensam..." (p.76). Neste poema apocalíptico, a destruição será levada a cabo por "eles" que, supõe-se, farão um mal semelhante ao da bomba de nêutron - aquela que só destrói as formas orgânicas: "Se vocês pensam que eles vão parar por aí,/ Estão enganados./ É que as gaiteiras, manimbus e aratus/ Já estão dizimados,/ A jaracuçu, a cobra verde,/ O uçá e o guaiamum/ Já bóiam de barriga para cima/ Entre o pântano e a lagoa". Todo esse mundo aquático, orgânico, viçoso, tão característico da cidade, será calcinado: "Ainda haver-se-á de passar pelas praias/ Vestido de astronauta, / Não que irão transformar as águas em lua,/ Mas ao contrário: em anti-lua". Quando não restar mais nem o corpo da cidade (outra vez antropomorfizada), pois devorada por "eles" em crua cena de canibalismo, sem o ritual sagrado da antropofagia tão caro aos índios da região, "[...] vão colorir a cidade pra dizer/ Que está tudo bonitinho”. Assim como caiu a cidade, a última palavra do poema provoca uma queda na tensão dramática que ascendia desde o início. O sentimento trágico do temor deságua num riso aguado, e não na pena. Este mesmo anticlímax se dá em "A saga do toureiro - o retorno" (p. 67), poema que descreve os preparativos de uma improvável tourada que ocorreria onde se encontram "A Câmara, a capela de Nossa Senhora dos Prazeres e a cadeia", local em que surge o primeiro núcleo humano que dará origem à cidade: "E onde fora o engenho os dois se chocam,/ Quer dizer: era o que todos esperavam,/ Mas não, apenas um passa pelo outro,/ Um ocupa o lugar do outro,/ O outro ocupa o lugar de um”.

Este livro de Paulo Renault (que, no caso de uma segunda edição, necessita de uma atenta revisão) como se pôde notar pelos fragmentos citados aqui, é todo composto por versos polimétricos que têm o tamanho da respira- 
ção, pois foram feitos antes para ser declamados do que lidos. Se o livro traz a visão de uma cidade destruída, também traz o desejo adâmico do poeta de reconstruí-la pelas palavras. No que diz respeito ao referente, e em comparação aos dois poetas acima abordados, Renault debruçou-se bem mais sobre o interior da cidade, sua parte voltada para lagoa ("a mãe do norte"), onde hoje habita a classe mais pobre, do que sobre o mar. Por exemplo, Jaraguá para ele é um lugar "inóspito", enquanto para Lêdo Ivo é, por deslizamento metonímico, o mar, os navios, os prostíbulos (para Marcos de Farias Costa também), os armazéns de secos e molhados, as lojas de ferragens. A cidade que Renault invoca ainda existe, quando não pela abundância dos lugares recorridos e percorridos, ainda que em ruína.

Depois deste arbitrário percurso pelas partes das obras dos três poetas que tiveram Maceió como tema, é inevitável realçar alguns pontos em comum entre eles e algumas diferenças significativas, procedimento crítico usual quando se trata de um corpus díspar.

O primeiro ponto em comum - além "d'une certaine sensibilité à l'espace, ou pour mieux dire une sorte de fascination du lieu" (GENETTE, 1969, p. 44) - é o desejo de fuga da cidade, empiricamente realizado por Lêdo Ivo, posto que de uma geração de homens de letras em que era comum a emigração para a cidade grande - geralmente o Rio de Janeiro, então capital da república e sede de grandes jornais e editoras. Marcos de Farias Costa e Paulo Renault já pertencem a uma geração onde a emigração não era imperativa e em Maceió nasceram e ficaram. A localização geográfica da cidade, à beira do mar, e seu motivo de viabilização, o porto, já são por si um convite à partida, que efetivamente se realizará no espaço textual. Mas o desejo de fuga é inerente a todo poeta maceioense ou a todo poeta, simplesmente?

Um segundo ponto em comum entre eles é a presença do que há de natureza na cidade (ainda que mitigada em Marcos de Farias Costa). Na grande parte dos poemas, é massivo o campo semântico pertencente ao elemento natural dominante em Maceió, desde a etimologia, 
qual seja, a água e tudo que lhe é correlato. Cidade banhada pelo Atlântico, por um lado, por outro, pela lagoa Mundaú, e cortada por lentos riachos (hoje apodrecidos por dejetos), além das chuvas torrenciais que não deixam seus habitantes esquecerem a definição do Aurélio da palavra "maceió", a água é incontornável tanto na vida, quanto na arte nativa. Ela é ao mesmo tempo o elemento primevo, uterino, e o meio de fuga - o mar. E por ser tão aquática, a cidade é freqüentemente antropomorfizada no feminino, mesmo que o substantivo comum "maceió" seja masculino - como num passe de mágica, a troca da minúscula pela maiúscula inicial a faz fêmea.

Do ponto de vista formal, mesmo que cada poeta tenha dicção bastante particular, observam-se confluências, devidas a uma questão histórica: são poetas do século $x x$, e que não negaram as linhas de força da poesia praticada neste século: a liberdade formal, a intertextualidade e o escrever contra - o metro fixo, a rima obrigatória, a pontuação normativa, o léxico estabelecido (daí a presença de neologismos), o bom gosto, a polidez, a eufonia na escolha vocabular, etc. E esses procedimentos formais estão em consonância com uma ética, qual seja, a de posicionar-se contra o poder dominante - político, social e econômico. É pelas bordas, pelas franjas, pelas margens (pela água) que o poder é visto.

Quanto às diferenças significativas, deve-se mencionar antes de tudo a geracional. Lêdo Ivo pertence à geração de 45, nasceu no Entre-guerras e era jovem na Segunda. Além do que já foi mencionado, partiu ainda jovem de Maceió, primeiro para Recife, depois para o Rio, onde se estabeleceu e vive até hoje. Conviveu com grandes personalidades literárias brasileiras do século xx (cf. Confissões de um poeta). Morou no exterior (Paris) e é um viajante contumaz - todas estas informações biográficas podem ser sacadas em seus livros, tanto os de poesia, quanto os em prosa. É um nome estabelecido na literatura brasileira - tem livros traduzidos e reeditados, é incluído em antologias escolares de grandes tiragens, pertence à Academia Brasileira de Letras e à Academia Alagoana, 
e não raro, participa de polêmicas, o que é mais um fator para deixá-lo em evidência. Já Marcos de Farias Costa e Paulo Renault são bem mais novos, pertencem à geração de 68, marcada pela luta pela liberalização dos costumes e contra a ditadura militar. Nenhum dos dois saiu de Maceió, fizeram suas carreiras literárias na cidade - também isto é refletido em suas obras, quando não nos paratextos.

Do ponto de vista formal, encontra-se em Lêdo Ivo e em Marcos de Farias Costa um certo controle do poema pela medida do verso (mas não de forma obrigatória, sectária), o uso ocasional de rimas e estrofes e o diálogo textual (implícito ou explícito) com outros escritores. Há em ambos, por isso, a marca da literatura como origem da literatura. Já Paulo Renault tem uma poesia mais "selvagem", oralizada, declamatória, mas sem os truques condoreiros da retórica de palanque - seria antes o desabafo altissonante de mesa de bar.

Quase todos os poemas dos três poetas sobre Maceió trazem uma ponta de sofrimento, de ironia ou de dissonância para com a cidade. Por ela, cada eu lírico tem sua paixão - crítica, inerente a todo poeta moderno. Mas ao menos escreveram sobre ela, ao contrário de tantos outros, que não quiseram, ou não souberam, emprestarlhe suas penas. 


\section{Referências}

BAUDELAIRE, Charles. Oeuvres complètes, v. I. Paris: Gallimard (La Pléiade), 1975.

. Oeuvres complètes, v.II. Paris: Gallimard (La Pléiade), 1976.

BENJAMIN, Walter. Charles Baudelaire - um lírico no auge do capitalismo. 3. ed. São Paulo: Brasiliense, 1994..

BRADBURY, Macolm. As cidades do modernismo. In: BRADBURY, Macolm; McFARLANE, James (orgs.) Modernismo - guia geral. São Paulo: Companhia das Letras, 1999. BUARQUE DE HOLANDA FERREIRA, Aurélio. Novo dicionário Aurélio da língua portuguesa. 2. ed.Rio de Janeiro: Nova Fronteira, 1986.

CAZANAVE, Claire. Espace. In: ARON, Paul et alii (orgs.). Le dictionnaire du Littéraire. Paris: Puf, 2002.

DUBOST, Jean-Pierre. Local, Lokalität: de Rousseau à Freud. In: AURAIX-JONCHIÈRE, Pascale e MONTANDON, Alan (orgs.). Poétique des lieux. Clermont Ferrand: Presses Universitaires Blaise Pascal, 2004.

ECO, Umberto. As formas do conteúdo. 3. ed. São Paulo: Perspectiva, 2001.

FARIAS COSTA, Marcos de. O amador de sonhos. Maceió: Sergasa, 1981. . Ócios do ofício. Maceió: Sergasa, 1984. - A quadratura do círculo. São Paulo: João Scortecci, 1991. - A comédia de Eros - poemas galantes. Maceió: Edição do autor, 1997. . Doce estilo novo. São Paulo: Barcarola, 2000. HIDALGO-BACHS, Bernardette. La spatialité de l'entredeux dans les trois premiers recueils de Pedro Salinas. In: AURAIX-JONCHIÈRE, Pascale e MONTANDON, Alan. Poétique des lieux. Clermont Ferrand: Presses Universitaires Blaise Pascal, 2004.

HYDE, G.M. A poesia da cidade. In: BRADBURY, Macolm; McFARLANE, James. (Orgs.). Modernismo - guia geral. São Paulo: Companhia das Letras, 1999. 
GENETTE, Gerard. La litératture et l'espace. In: Figures II. Paris: Seuil, 1969.

IVO, Lêdo. Ninho de cobras. Maceió: Catavento, 2002 . Confissões de um poeta. 4. ed. Rio de Janeiro:

Topbooks, 2004. . Poesia completa - 1940-2004. Rio de Janeiro:

Topbooks, 2004.

NERVAL, Gérard de. Les Chimères, La Bohême galante, Petis châteaux de Bohême. Paris: Gallimard, 2005.

RENAULT, Paulo. A saga do toureiro. Maceió: Funted, 1994. . Maceió cidade aberta. Maceió: Catavento, 2004.

WESTPHAL, Bertrand. Le spectre d'Ulysse ou les aléas du référent. In: AURAIX-JONCHIĖRE, Pascale; MONTANDON, Alan (Orgs.). Poétique des lieux. Clermont Ferrand: Presses Universitaires Blaise Pascal, 2004. 